\title{
Short Communication: Comparison of Protocols to Estimate Twenty-Four-Hour Fat and Protein Percentages for Herds with a Robotic Milking System
}

\author{
K. J. Hand, ${ }^{*}$ D. Lazenby, ${ }^{*}$ F. Miglior, $\$ \neq^{1}$ and D. F. Kelton§ \\ ${ }^{*}$ CanWest Dairy Herd Improvement, Guelph, ON, Canada, N1K 1 E5 \\ †Agriculture and Agri-Food Canada, Dairy and Swine Research and Development Centre, Lennoxville, QC, Canada, J1M 1 Z3 \\ ¥Canadian Dairy Network, Guelph, ON, Canada, N1G 4T2 \\ §Dept. of Population Medicine, University of Guelph, Guelph, ON, Canada, N1G 2W1
}

\section{ABSTRACT}

Currently, different protocols are used in various countries to estimate the 24 -h fat and protein percentages for dairy cows that are milked with an automatic milking system. These protocols include estimating 24$\mathrm{h}$ fat and protein percentages from 1) single samples from all animals in the herd; 2) single samples of fat adjusted for covariates and single samples of protein unadjusted for covariates; or 3) all samples (adjusted and unadjusted) collected on test days where test days vary in length from 10 to $18 \mathrm{~h}$. The accuracy of estimated component percentages in predicting observed percentages was determined via agreement analysis for four protocols. Analysis of the data suggests collecting all samples (unadjusted for covariates) during a sampling period of at least $16 \mathrm{~h}$ on test day to be the most accurate protocol when estimating 24-h fat and protein percentages in herds with automatic milking systems. Key words: milk recording, sampling protocol, automatic milking system

Milk recording programs and genetic evaluation programs require 24-h estimates of fat and protein percentages. Accurate and reliable 24 -h fat and protein percentages can be estimated for herds milked 2 and 3 times daily. However, in herds with an automatic milking system (AMS), the estimation of reliable and accurate yields poses a challenge. On Canadian AMS farms, with the use of specialized equipment, all milk samples within a 24-h period are collected and analyzed for composition. The number of samples collected as well as the interval between samples varies among cows within a herd. Collecting and analyzing all milk samples within a 24 -h period is very costly in terms of labor and sample analysis. Consequently, various protocols and

Received October 11, 2005.

Accepted December 14, 2005.

${ }^{1}$ Corresponding author: miglior@cdn.ca methods have been suggested to reduce the sampling period and number of samples collected (Bouloc et al., 2002; Lazenby et al., 2002; Peeters and Galesloot, 2002). Ideally, although protocols to estimate 24-h fat and protein percentages save on time, effort, and costs, the estimates need to accurately represent the actual 24-h percentages. The objective of this study was to examine the agreement between observed and estimated 24-h fat and protein percentages from AMS herds using 4 different protocols that are currently used in various countries.

Four protocols (P1 to P4) used in this study for estimating 24-h fat and protein percentages are summarized in Table 1. The covariates in P2, which resembles the protocol proposed by Peeters and Galesloot (2002), included fat and protein percentages of sampled milking, milking interval of sampled milking and previous milking as well as milk yield of sampled milking and previous milking. The covariates in P3 included parity, DIM, season ( 1 = October to April; 2 = May to September), test-day milk yield, log (test-day fat percentage), log (test-day protein percentage), and the random component of herd. Test-day milk records and samples were collected from 12 robotic herds in Ontario, Canada. The data were collected over 94 test days for a total of 12,980 sample records. For each animal in the herd on test day, 24-h percentages of fat and protein were observed. Following protocols $\mathrm{P} 1$ to $\mathrm{P} 4,24$-h percentages of fat and protein were then estimated. Agreement between observed and estimated fat and protein percentages was examined. Often, the Pearson correlation coefficient is used as a measure of agreement. Although the Pearson correlation coefficient can measure the degree of linear association between pairs of measurements, it is a poor measure of agreement. Lin (1989) introduced a concordance correlation as a measure of reproducibility. The concordance correlation is a measure of association as well as agreement. Concordance correlations range in value from -1 to 1 , where \pm 1 represents perfect agreement. Concordance correlations between the observed and estimated fat and protein percentages were 
Table 1. Descriptions of sampling protocols (P1 to P4) used in herds with automatic milking systems

\begin{tabular}{ll}
\hline Protocol & Description \\
\hline P1 & Within a 24-h period, use single samples unadjusted for covariates where milk intervals must be greater than or equal to $8 \mathrm{~h}$. \\
P2 & Within a 24-h period, use single samples for fat and protein with only fat adjusted for covariates where milk intervals must \\
& be greater than or equal to $4 \mathrm{~h}$. \\
P3 & Use all samples adjusted for covariates for sampling intervals of $10,12,14,16$, and $18 \mathrm{~h}$. \\
P4 & Use all samples unadjusted for covariates for sampling intervals of $10,12,14,16$, and $18 \mathrm{~h}$. \\
\hline
\end{tabular}

calculated for all protocols. Agreement lines were estimated (regression of observed percentage on estimated percentage). When agreement is perfect, the slope parameter is 1 and the intercept 0 (a perfect $45^{\circ}$ line). When the slope is close to 1 , the intercept is a measure of the estimation bias. When the slope is not equal to 1 , the estimated percentage over- or underestimates the true 24-h percentage. The method of Bland and Altman (1986) was also used to check for systematic bias and outliers. The Bland and Altman (1986) plots consist of plotting the difference between observed and predicted means (D) against the average of the observed and predicted responses. Lastly, 95\% tolerance intervals for $\mathrm{D}$ were calculated with $95 \%$ confidence (the values of $\mathrm{D}$ that contain $95 \%$ of the population). All analyses were performed using SAS (SAS Institute, 1999).

The slopes and intercepts for the agreement lines for fat percentage are shown in Table 2. The estimates of the concordance correlations as well as the $95 \%$ tolerance intervals for $\mathrm{D}$ for fat percentage are found in Table 3. Confidence intervals for the slope in Table 2 showed that only P4 included the value of 1 , although the estimated values were close to 1 for P1 also. Confidence intervals for the intercept in Table 2 included 0 only for protocol P4. The results for protocols P2 and P3 compared with $\mathrm{P} 4$ were expected as regression methods may introduce error due to prediction. All protocols had concordance correlations approaching 1 . Tolerance intervals for D were smallest for P3 (16 and $18 \mathrm{~h}$ ) and P4 (16 and $18 \mathrm{~h}$ ). The Bland and Altman (1986) method did not reveal systematic bias.

The slopes and intercepts for the agreement lines for protein percentage are shown in Table 4 . Table 5 shows the estimates of the concordance correlations as well as the $95 \%$ tolerance intervals for $\mathrm{D}$ for protein percentage. None of the confidence intervals for the slope in Table 4 included the value of 1 , although the estimated values were close to 1 for P1, P2, and P4. Confidence intervals for the intercept in Table 4 included 0 only for P1, although the estimated values were close to 0 for P2 and P4. All protocols had concordance correlations approaching 1 . Tolerance intervals for $\mathrm{D}$ were smallest for P3 (16 and $18 \mathrm{~h})$ and P4 (16 and $18 \mathrm{~h})$. The Bland and Altman (1986) method did not reveal systematic bias. Sampling period started mostly early in the morning. In a separate analysis time of sampling (morning vs. night) was included and results (not shown) were very similar to results presented in Tables 2 to 5 .

Producers with AMS need to reduce the cost and effort involved in milk sample collection and analysis to estimate 24-h fat and protein percentages. However, it is imperative, before adopting any protocol, to ensure these protocols lead to estimates that are unbiased and reliable. Concerning protein percentage, there were no great discrepancies among protocols. The limiting crite-

Table 2. Ninety-five percent confidence intervals and estimates of linear agreement lines for 24-h fat percentage

\begin{tabular}{|c|c|c|c|c|c|c|c|c|}
\hline \multirow[b]{2}{*}{ Protocol } & \multirow[b]{2}{*}{$\begin{array}{l}\text { Sampling } \\
\text { interval, } \mathrm{h}\end{array}$} & \multirow[b]{2}{*}{$\begin{array}{l}\text { No. of } \\
\text { cows }\end{array}$} & \multicolumn{3}{|c|}{ Intercept } & \multicolumn{3}{|c|}{ Slope } \\
\hline & & & $\begin{array}{l}\text { Lower } \\
\text { limit }\end{array}$ & Estimate & $\begin{array}{l}\text { Upper } \\
\text { limit }\end{array}$ & $\begin{array}{l}\text { Lower } \\
\text { limit }\end{array}$ & Estimate & $\begin{array}{l}\text { Upper } \\
\text { limit }\end{array}$ \\
\hline P1 & & 6,164 & -0.1969 & -0.1520 & -0.1071 & 1.0046 & 1.0164 & 1.0282 \\
\hline P2 & & 4,839 & 1.0096 & 1.0506 & 1.0916 & 0.6950 & 0.7059 & 0.7168 \\
\hline \multirow[t]{5}{*}{ P3 } & 10 & 5,417 & 0.8037 & 0.8421 & 0.8804 & 0.7611 & 0.7712 & 0.7814 \\
\hline & 12 & 5,856 & 0.8622 & 0.9090 & 0.9559 & 0.7417 & 0.7541 & 0.7664 \\
\hline & 14 & 6,110 & 0.5354 & 0.5684 & 0.6014 & 0.8390 & 0.8477 & 0.8564 \\
\hline & 16 & 6,246 & 0.1130 & 0.1466 & 0.1802 & 0.9670 & 0.9758 & 0.9847 \\
\hline & 18 & 6,308 & 0.3266 & 0.3531 & 0.3797 & 0.8985 & 0.9055 & 0.9125 \\
\hline \multirow[t]{5}{*}{ P4 } & 10 & 5,417 & -0.0747 & -0.0235 & 0.0278 & 0.9931 & 1.0066 & 1.0202 \\
\hline & 12 & 5,856 & -0.0524 & -0.0077 & 0.0369 & 0.9913 & 1.0031 & 1.0149 \\
\hline & 14 & 6,110 & -0.0265 & 0.0129 & 0.0523 & 0.9888 & 0.9992 & 1.0095 \\
\hline & 16 & 6,246 & -0.0168 & 0.0174 & 0.0516 & 0.9901 & 0.9991 & 1.0081 \\
\hline & 18 & 6,308 & -0.0014 & 0.0281 & 0.0576 & 0.9895 & 0.9973 & 1.0051 \\
\hline
\end{tabular}


Table 3. Concordance correlations and 95\% tolerance intervals for D (predicted means) relative to estimation of 24 -h fat percentage

\begin{tabular}{lllll}
\hline Protocol & $\begin{array}{l}\text { Sampling } \\
\text { interval, } h\end{array}$ & $\begin{array}{l}\text { Concordance } \\
\text { correlation }\end{array}$ & $\begin{array}{l}\text { Lower } \\
\text { limit }\end{array}$ & $\begin{array}{l}\text { Upper } \\
\text { limit }\end{array}$ \\
\hline P1 & & 0.8955 & -0.6404 & 0.8219 \\
P2 & & 0.8555 & -0.6797 & 0.7452 \\
P3 & 0.8867 & -0.6675 & 0.6782 \\
& 10 & 0.8364 & -0.8332 & 0.8431 \\
& 14 & 0.9219 & -0.5838 & 0.5787 \\
& 16 & 0.9362 & -0.6068 & 0.4934 \\
P4 & 0.9531 & -0.4620 & 0.4582 \\
& 18 & 0.8862 & -0.7717 & 0.7696 \\
& 12 & 0.9045 & -0.7069 & 0.6997 \\
& 14 & 0.9209 & -0.6450 & 0.6255 \\
& 16 & 0.9380 & -0.5731 & 0.5448 \\
& 18 & 0.9525 & -0.5029 & 0.4668 \\
\hline
\end{tabular}

Table 4. Ninety-five percent confidence intervals and estimates of linear agreement lines for 24-h protein percentage

\begin{tabular}{|c|c|c|c|c|c|c|c|c|}
\hline \multirow[b]{2}{*}{ Protocol } & \multirow[b]{2}{*}{$\begin{array}{l}\text { Sampling } \\
\text { interval, } \mathrm{h}\end{array}$} & \multirow[b]{2}{*}{$\begin{array}{l}\text { No. of } \\
\text { cows }\end{array}$} & \multicolumn{3}{|c|}{ Intercept } & \multicolumn{3}{|c|}{ Slope } \\
\hline & & & $\begin{array}{l}\text { Lower } \\
\text { limit }\end{array}$ & Estimate & $\begin{array}{l}\text { Upper } \\
\text { limit }\end{array}$ & $\begin{array}{l}\text { Lower } \\
\text { limit }\end{array}$ & Estimate & $\begin{array}{l}\text { Upper } \\
\text { limit }\end{array}$ \\
\hline $\mathrm{P} 1$ & & 6,164 & -0.0402 & -0.0181 & 0.0040 & 0.9991 & 1.0056 & 1.0122 \\
\hline P2 & & 4,839 & 0.0129 & 0.0440 & 0.0751 & 0.9766 & 0.9859 & 0.9952 \\
\hline \multirow[t]{5}{*}{ P3 } & 10 & 5,417 & 0.6841 & 0.7295 & 0.7749 & 0.7676 & 0.7810 & 0.7945 \\
\hline & 12 & 5,856 & 0.3192 & 0.3386 & 0.3579 & 0.9152 & 0.9210 & 0.9267 \\
\hline & 14 & 6,110 & 0.1997 & 0.2175 & 0.2354 & 0.9529 & 0.9582 & 0.9635 \\
\hline & 16 & 6,246 & 0.1355 & 0.1515 & 0.1676 & 0.9741 & 0.9789 & 0.9837 \\
\hline & 18 & 6,308 & 0.1518 & 0.1659 & 0.1799 & 0.9679 & 0.9721 & 0.9762 \\
\hline \multirow[t]{5}{*}{$\mathrm{P} 4$} & 10 & 5,417 & -0.0866 & -0.0624 & -0.0383 & 1.0122 & 1.0194 & 1.0266 \\
\hline & 12 & 5,856 & -0.0663 & -0.0449 & -0.0234 & 1.0079 & 1.0143 & 1.0207 \\
\hline & 14 & 6,110 & -0.0523 & -0.0334 & -0.0145 & 1.0057 & 1.0113 & 1.0170 \\
\hline & 16 & 6,246 & -0.0399 & -0.0233 & -0.0067 & 1.0036 & 1.0085 & 1.0135 \\
\hline & 18 & 6,308 & -0.0396 & -0.0250 & -0.0104 & 1.0045 & 1.0089 & 1.0132 \\
\hline
\end{tabular}

Table 5. Concordance correlations and 95\% tolerance intervals for $\mathrm{D}$ (predicted means) relative to estimation of 24 -h protein percentage

\begin{tabular}{lllll}
\hline Protocol & $\begin{array}{l}\text { Sampling } \\
\text { interval, } \mathrm{h}\end{array}$ & $\begin{array}{l}\text { Concordance } \\
\text { correlation }\end{array}$ & $\begin{array}{l}\text { Lower } \\
\text { limit }\end{array}$ & $\begin{array}{l}\text { Upper } \\
\text { limit }\end{array}$ \\
\hline P1 & & 0.9670 & -0.1985 & 0.1970 \\
P2 & & 0.9475 & -0.2364 & 0.2421 \\
P3 & 0.8336 & -0.4153 & 0.4216 \\
& 10 & 0.9501 & -0.2516 & 0.1021 \\
& 14 & 0.9552 & -0.2388 & 0.0830 \\
& 16 & 0.9587 & -0.2254 & 0.0636 \\
P4 & 18 & 0.9671 & -0.2009 & 0.0561 \\
& 10 & 0.9653 & -0.2040 & 0.1993 \\
& 12 & 0.9702 & -0.1880 & 0.1824 \\
& 14 & 0.9756 & -0.1719 & 0.1630 \\
& 16 & 0.9806 & -0.1538 & 0.1435 \\
& 18 & 0.9848 & -0.1369 & 0.1277 \\
\hline
\end{tabular}


rion, therefore, was the estimation of 24-h fat percentage. Among the 4 studied protocols, $\mathrm{P} 4$ was the most accurate, because it was the only protocol with no bias and with no discernible over- or underestimation of fat percentage. Protocol P4 also resulted in one of the smallest tolerance intervals for D. A sampling period of $16 \mathrm{~h}$ at test day would decrease the amount of effort and expense for the producer without significantly decreasing the accuracy of 24 -h fat and protein percentages estimates.

\section{ACKNOWLEDGMENTS}

The authors would like to thank the 2 anonymous reviewers who helped to improve the manuscript.

\section{REFERENCES}

Bland, M., and D. Altman. 1986. Statistical methods for assessing agreement between two methods of clinical measurement. Lancet $\mathrm{i}: 307-310$

Bouloc, N., V. Dervishi, and J. Delacroix. 2002. Milk recording and automatic milking systems: Simplification by reducing the daily time test from 24 to 12 hours. Pages 57-63 in EAAP Publication 107: Proc. 33rd ICAR Session Meeting, Interlaken, Switzerland. EAAP, Rome, Italy.

Lazenby, D., E. Bohlsen, K. J. Hand, D. F. Kelton, F. Miglior, and K. D. Lissemore. 2002. Methods to estimate 24-h yields for milk, fat and protein in robotic milking herds. Pages 65-71 in EAAP Publication 107: Proc. 33rd ICAR Session Meeting, Interlaken, Switzerland. EAAP, Rome, Italy.

Lin, L. I. 1989. A concordance correlation coefficient to evaluate reproducibility. Biometrics 45:255-268.

Peeters, R., and P. J. B. Galesloot. 2002. Estimating daily fat yield from a single milking on test day for herds with a robotic milking system. J. Dairy Sci. 85:682-688.

SAS Institute. 1999. SAS/STAT User's Guide. Version 8. SAS Inst., Inc., Cary, NC. 